\title{
6. GAS HYDRATES OF THE BLAKE OUTER RIDGE, SITE 533, DEEP SEA DRILLING PROJECT LEG 76'
}

\author{
Keith A. Kvenvolden, U.S. Geological Survey, Menlo Park, California \\ and \\ Leo A. Barnard, Department of Oceanography, Texas A\&M University, College Station, Texas
}

\begin{abstract}
Natural gas hydrates are clathrates in which water molecules form a crystalline framework that includes and is stabilized by natural gas (mainly methane) at appropriate conditions of high pressures and low temperatures. The conditions for the formation of gas hydrates are met within continental margin sediments below water depths greater than about $500 \mathrm{~m}$ where the supply of methane is sufficient to stabilize the gas hydrate. Observations on DSDP Leg 11 sug. gested the presence of gas hydrates in sediments of the Blake Outer Ridge. Leg 76 coring and sampling confirms that, indeed, gas hydrates are present there. Geochemical evidence for gas hydrates in sediment of the Blake Outer Ridge includes (1) high concentrations of methane, (2) a sediment sample with thin, matlike layers of white crystals that released a volume of gas twenty times greater than its volume of pore fluid, (3) a molecular distribution of hydrocarbon gases that excluded hydrocarbons larger than isobutane, (4) results from pressure core barrel experiments, and (5) pore-fluid chemistry. The molecular composition of the hydrocarbons in these gas hydrates and the isotopic composition of the methane indicate that the gas is derived mainly from microbiological processes operating on the organic matter within the sediment. Although gas hydrates apparently are widespread on the Blake Outer Ridge, they probably are not of great economic significance as a potential, unconventional, energy resource or as an impermeable cap for trapping upwardly migrating gas at Site 533 .
\end{abstract}

\section{INTRODUCTION}

Hydrates of natural gas are a special kind of clathrate in which a three-dimensional framework of water molecules includes and is stabilized by molecules of natural gas, mainly methane $\left(C_{1}\right)$. In this framework, water crystallizes in the isometric (cubic) system rather than in the hexagonal system of normal ice. The cubic lattice contains cages that are large enough to accommodate molecules of gas. Two structures of the cubic lattice are possible. In Structure I, the cages are arranged in bodycentered packing and include small molecules such as $C_{1}$ and ethane $\left(\mathrm{C}_{2}\right)$ and nonhydrocarbons such as $\mathrm{CO}_{2}, \mathrm{~N}_{2}$, and $\mathrm{H}_{2} \mathrm{~S}$ (Fig. 1). In Structure II, diamond packing is present; not only can $C_{1}$ and $C_{2}$ be included in the cages, but propane $\left(\mathrm{C}_{3}\right)$ and isobutane $\left(\mathrm{i}-\mathrm{C}_{4}\right)$ are also needed to occupy some of the larger cages in order to stabilize the structure (Fig. 1). Apparently gases larger than $\mathrm{i}-\mathrm{C}_{4}$, (i.e., $n$-butane $\left[n-\mathrm{C}_{4}\right]$ or the pentanes $\left[\mathrm{C}_{5}\right]$ ) cannot be included in either Structure I or II. A more complete discussion of the crystallography of natural gas hydrates is given by Hitchon (1974).

Under an appropriate regime of pressure and temperature, natural gas can interact with water to form Structure I gas hydrates. Structure II hydrates are not expected unless the gas is relatively rich in larger hydrocarbons such as $C_{3}$ and i- $C_{4}$ (Davidson et al., 1978). The pressure-temperature stability field of natural gas hydrates indicates that at pressures greater than about 25 atm the gas hydrate exists at temperatures increasingly

\footnotetext{
${ }^{1}$ Sheridan, R. E., Gradstein, F. M., et al., Init. Repts. DSDP, 76: Washington (U.S Govt. Printing Office).
}

higher than the freezing point of water (Fig. 2). The amount of $C_{1}$ needed to form gas hydrates also depends on temperature and pressure and must be in excess of the amount soluble in water at these conditions. Natural gas hydrates can form in oceanic sediments at water depths greater than about $500 \mathrm{~m}$ where bottom water temperatures approach $0^{\circ} \mathrm{C}$. Solid gas hydrates have been recovered from sediments of the Black Sea (Yefremova and Zhizhchenko, 1974), the landward wall of the Middle American Trench off Mexico (Moore, Watkins, et al., 1979), and the landward wall of the same Trench off Guatemala (von Huene, Aubouin, et al., 1980). Within the sediments the geothermal gradient limits the depths at which gas hydrates can occur. The fact that the temperature of sediments increases with depth leads to temperature conditions at which gas hydrates are no longer stable and therefore decompose. The base of the gas hydrate follows a pressure-temperature surface that represents the maximum depth at which the gas hydrate is stable.

The base of the gas hydrate often correlates with anomalous acoustic reflectors in marine seismic profiles obtained from a number of areas on outer continental margins (Shipley et al., 1979). The anomalous reflector approximately parallels the seafloor but deepens with increasing water depths. The depths at which this reflector occurs can be predicted based on considerations of the pressure-temperature stability field (Fig. 2) and the geothermal gradient. This reflector is commonly called a bottom-simulating reflector (BSR). The reflector probably results from the velocity contrast between sediment cemented with gas hydrate and the underlying sediment where lower velocities occur because of the absence of 


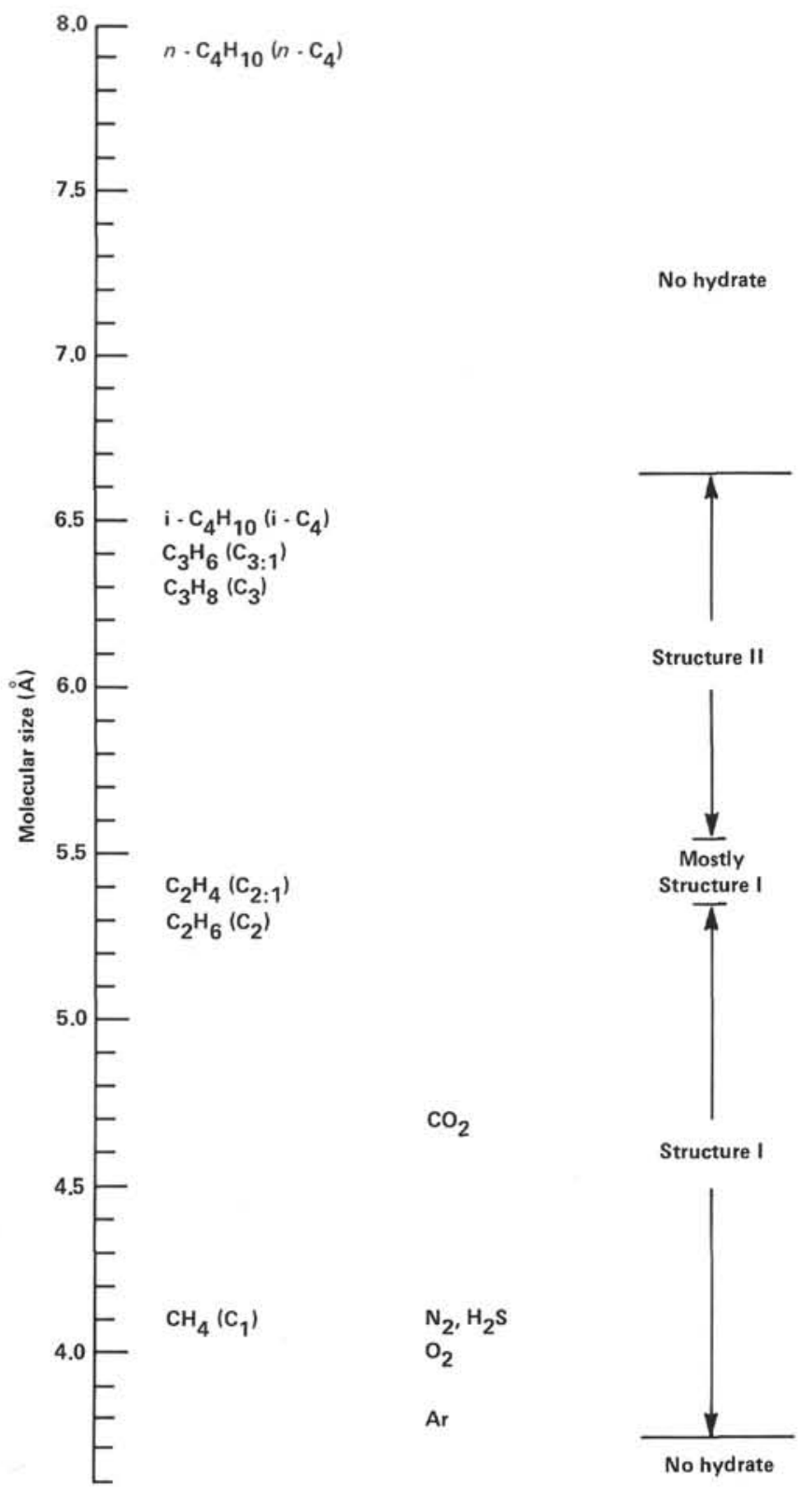

Figure 1. Naturally occurring molecules that form simple gas hydrates arranged in order of size. (Adapted from Davidson [1973] and Hand et al. [1974].)

gas hydrate and the possible presence of free gas. Kvenvolden and McMenamin (1980) and Kvenvolden and Barnard (in press) have summarized the geologic occurrence of natural gas hydrates and listed areas where gas hydrates in oceanic sediments have been inferred based on observations of BSRs on marine seismic records. Apparently natural gas hydrates are present in continental margin sediments in all major oceans. One area for which seismic records show a particularly well-developed BSR (Fig. 3) is the Blake Outer Ridge (Fig. 4), and this report considers the geophysical and geochemical evidence for gas hydrates in this region and particularly at Deep Sea Drilling Project, International Phase of Ocean Drilling (DSDP/IPOD) Site 533.

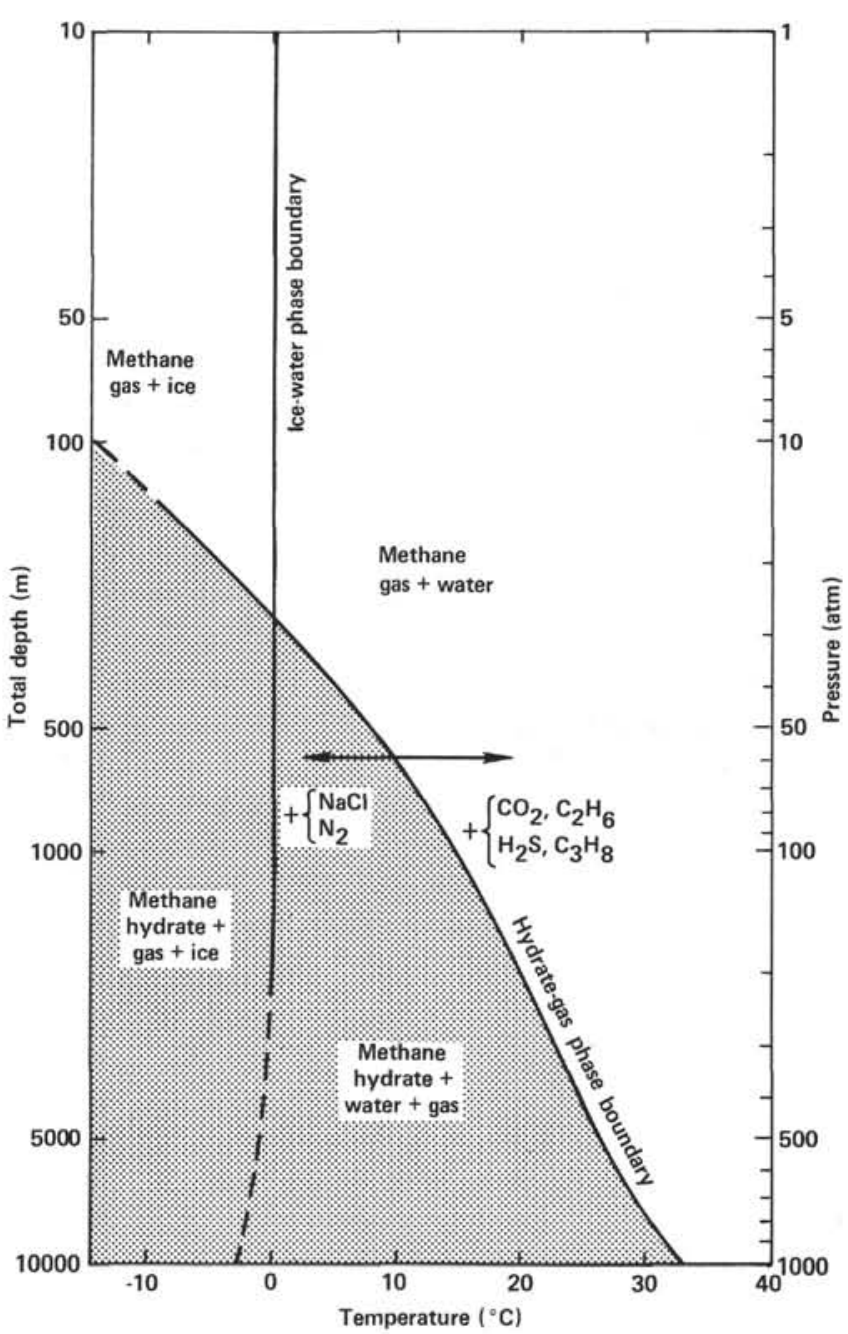

Figure 2. Phase boundary diagram showing free methane gas and methane hydrate (pattern) for a pure water and pure methane system. (Addition of $\mathrm{NaCl}$ to water and of $\mathrm{N}_{2}$ shifts the curve to the left. Additions of $\mathrm{CO}_{2}, \mathrm{H}_{2} \mathrm{~S}, \mathrm{C}_{2}$, and $\mathrm{C}_{3}$ to $\mathrm{C}_{1}$ shift the boundary to the right. Arrows indicate the direction but not the magnitude of the shifts. Depth scale is an approximation based on the assumption that lithostatic and hydrostatic pressure gradients are both 0.1 atmosphere per meter. Redrawn after Katz et al. [1959] and modified from Kvenvolden and McMenamin [1980].)

\section{EARLY EVIDENCE FOR GAS HYDRATES IN SEDIMENTS OF THE BLAKE OUTER RIDGE}

Seismic profiles in the area of the Blake Outer Ridge in the western Atlantic Ocean off the southeastern United States by Markl et al. (1970) showed an anomalous acoustic reflector (BSR) that was later interpreted to correlate with the base of gas hydrate (Ewing and Hollister, 1972; Tucholke et al., 1977; Shipley et al., 1979; Dillon et al., 1980). This BSR has been mapped over an area of approximately $80,000 \mathrm{~km}^{2}$ (estimated from a map presented by Dillon et al. [1980]), suggesting that gas hydrate is widespread at the Blake Outer Ridge (Fig. 4).

Besides seismic profiling, acoustic velocities of sediments have also been measured at the Blake Outer 


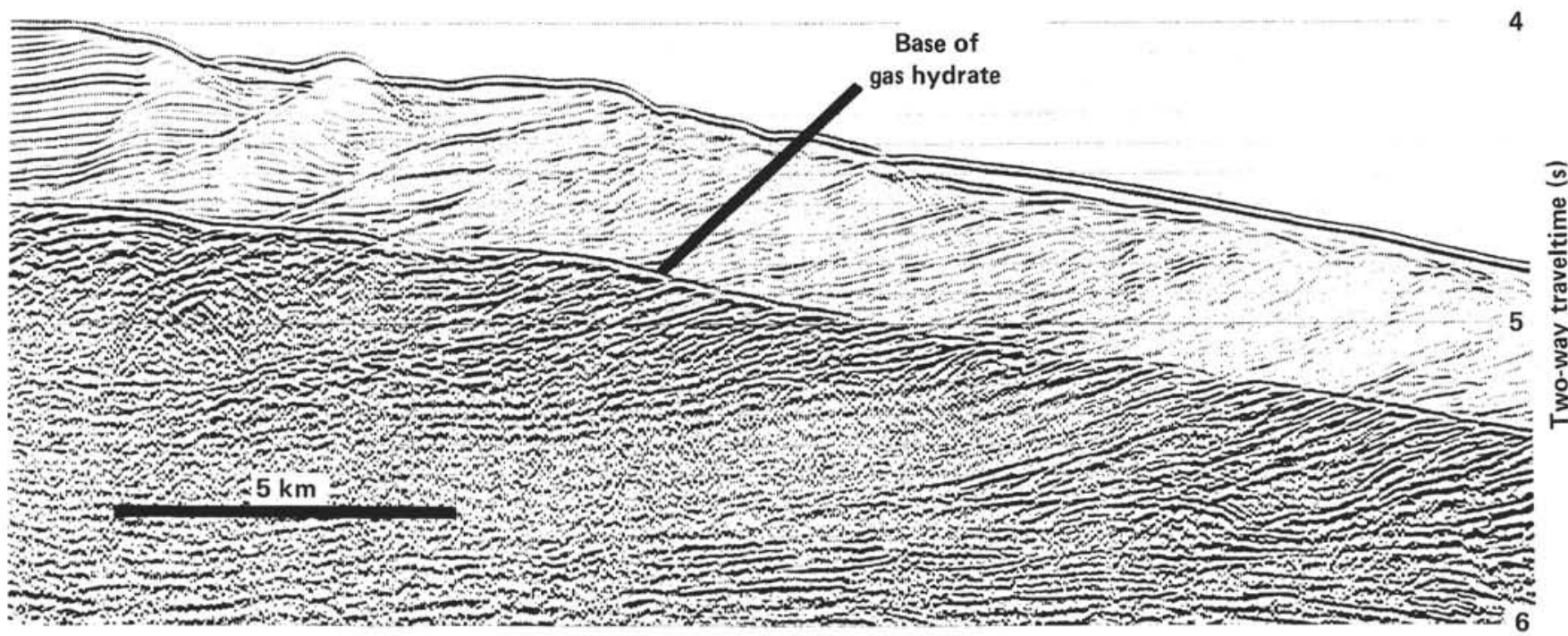

Figure 3. A 12-fold multichannel seismic reflection profile from the crest and eastern flank of the Blake Outer Ridge. (The reflector probably marks the base of the gas hydrate and follows the bathymetry of the seafloor and transects dipping bedding reflectors [Shipley et al., 1979, fig. 3, p. 2206].)

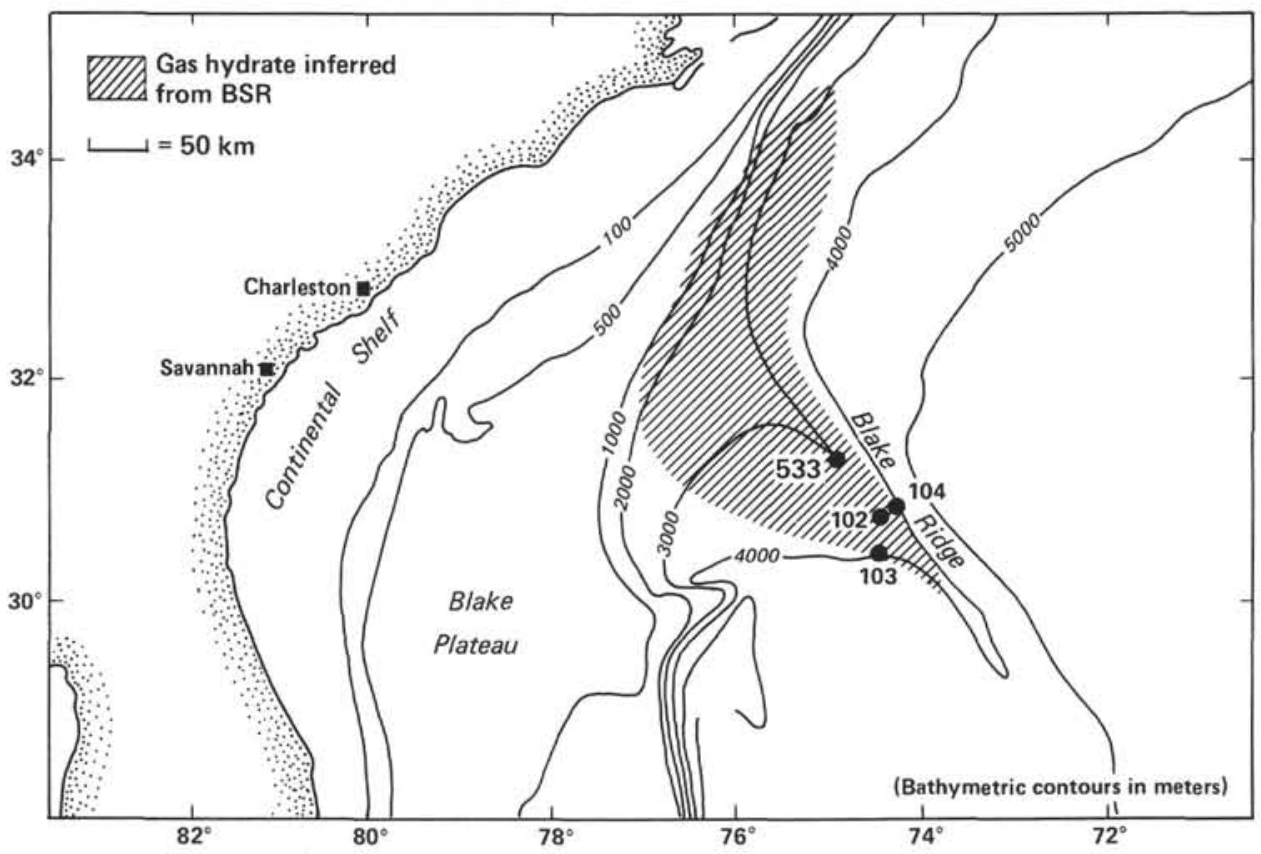

Figure 4. Location of Site 533, Leg 76, and Sites 102, 103, and 104, Leg 11. (A bottom-simulating reflector suggesting the presence of gas hydrates has been mapped by Dillon et al. [1980] at the Blake Outer Ridge, and the areal extent $\left[\cong 80,000 \mathrm{~km}^{2}\right]$ of this inferred gas hydrate is shown.)

Ridge. The apparent acoustic velocity through the sediment overlying the BSR was determined to be about 2 $\mathrm{km} / \mathrm{s}$ (Lancelot and Ewing, 1972), a velocity unusually high for hemipelagic sediment. Further studies of acoustic velocities at the Blake Outer Ridge support this first observation. For example, Bryan (1974) confirmed the value of $2 \mathrm{~km} / \mathrm{s}$ by independent sonobuoy measurements. Dillon et al. (1980) calculated from multichannel seismic velocity analyses that the sediment above the BSR has a velocity greater than $2.5 \mathrm{~km} / \mathrm{s}$ and that below the BSR the velocity is less than $1.5 \mathrm{~km} / \mathrm{s}$. Sonobuoy velocities of $2.3 \mathrm{~km} / \mathrm{s}$ above the BSR and $1.8 \mathrm{~km} / \mathrm{s}$ below were determined on DSDP/IPOD Leg 76 prior to positioning the ship at Site 533 (Site 533 report, this volume). Although the velocity determinations do not precisely agree, there is generally a consensus that the velocity in the presumed gas hydrate-containing sediment above the BSR is greater than the velocity in the sediment beneath the BSR. Such a velocity inversion would result in a negative reflection coefficient and polarity 
reversal, and Shipley et al. (1979) showed, on the basis of digital seismic data from the Blake Outer Ridge and elsewhere, that a reflection polarity reversal is associated with the BSR.

An objective of DSDP Leg 11 (Ewing and Hollister, 1972) was to investigate the causes of the BSR seen on seismic profiles along the Blake Outer Ridge. Sediment samples recovered at DSDP Sites 102, 103, and 104 (Fig. 4) yielded high concentrations of gas. In many cases gas expansion was sufficient to extrude sediment from core liners. Degassing occurred immediately when the cores were opened, and many cores continued to produce gas for several hours afterwards (Lancelot and Ewing, 1972). The gas was principally methane with usually less than $0.04 \%$ ethane (Paulus, 1972). The carbon isotopic composition of methane at Sites 102 and 104 ranged from -70.1 to -88.4 per mil, relative to the Peedee belemnite (PDB) standard (Claypool et al., 1973). No obvious solid gas hydrates were observed, however. Nevertheless, the occurrence of gas hydrates in sediments at these sites was postulated by Stoll et al. (1971), Ewing and Hollister (1972), and Lancelot and Ewing (1972), based on the concurrence of the geophysical and geochemical evidence obtained.

The strong indirect evidence for gas hydrates in sediments of the Blake Outer Ridge led to the drilling of two holes at Site 533 . Hole 533 was continuously cored with a hydraulic piston core from the surface to a sub-bottom depth of $168 \mathrm{~m}$. Hole 533A was rotary cored from $57 \mathrm{~m}$, with continuous core recovery from 143 to $399 \mathrm{~m}$.
A main objective at this site was to attempt to recover gas hydrates and thoroughly document their occurrence. Our approach, outlined in the Site 533 report (this volume), consisted of five phases: (1) analyses of gases recovered by means of vacutainers from void spaces (gas pockets) in core liners; (2) headspace analyses of gases extracted from sediment samples; (3) pressure and volume measurements obtained upon the decomposition of suspected gas hydrates and subsequent analyses of the evolved gases; (4) analyses of gases obtained from a pressure core barrel during sequential release of gas at different temperatures; and (5) collection of samples for further shore-based studies.

\section{GASES IN SEDIMENTS AT SITE 533}

The Site 533 report (this volume) presents results of our shipboard analyses of gases collected by (1) vacutainers from gas pockets formed within core liners by gas expansion during core recovery and by (2) extraction from sediments into a helium headspace, along with details of the analytical procedures used. Our purpose here is to summarize some of these results and indicate trends that were observed. Gas pockets occurred sporadically in cores from 25 to $50 \mathrm{~m}$ sub-bottom. Most cores from sub-bottom depths greater than $50 \mathrm{~m}$ contained gas pockets from which samples could be removed for analysis. Figure 5 shows the concentrations (relative to total gas) of gases recovered with depth from gas pockets: $\mathrm{C}_{1}$; $\mathrm{C}_{2}$; the sum of $\mathrm{C}_{3}, \mathrm{i}-\mathrm{C}_{4}, n-\mathrm{C}_{4}$, isopentane i- $\mathrm{C}_{5}$, and normal pentane $n-\mathrm{C}_{5}$; and $\mathrm{CO}_{2}$. In the measurement from

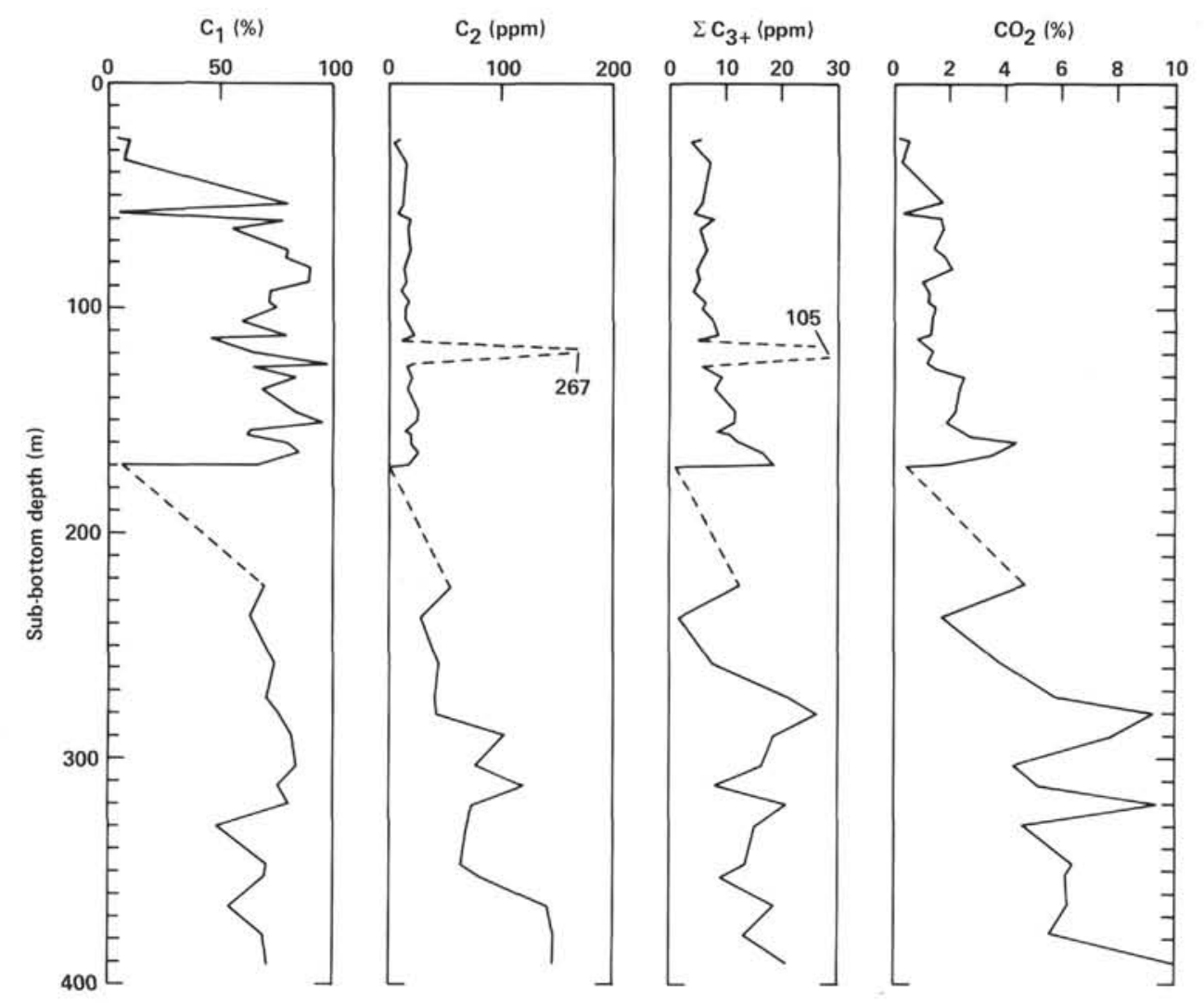

Figure 5. Concentration profiles with sub-bottom depth of $\mathrm{C}_{1}, \mathrm{C}_{2}, \mathrm{CO}_{2}$, and the sum of $\mathrm{C}_{3}, \mathrm{i}-\mathrm{C}_{4}, n-\mathrm{C}_{4}$, $\mathrm{i}-\mathrm{C}_{5}$, and $n-\mathrm{C}_{5}$ in gas pockets formed in sediments of Site 533 . 
gas pockets, the presence of atmospheric air is always a problem. For example, the vacutainers used for collection of gas have a residual background of air. Air also can be incorporated during sampling and during analysis. Although efforts were made to reduce the presence of air, and analyses were performed as consistently as possible, our results suggest that air is always a component of the gas analyzed. The amount of air contamination is probably greatest where the total concentration of gas in the sediments is lowest. Thus in the most shallow gas pockets, the low $\mathrm{C}_{1}$ contents reflect low absolute $\mathrm{C}_{1}$ concentrations in the sediments.

$\mathrm{C}_{1}$ and $\mathrm{CO}_{2}$ are the principal carbon-containing gases identified in the gas pockets; $\mathrm{C}_{1}$ constitutes more than $99 \%$ of the hydrocarbon gases present. Preliminary measurements also indicate that $\mathrm{N}_{2}$ in excess of that found in air is also present (W. C. Evans, U.S. Geological Survey, personal communication, 1981). Below a sediment depth of $50 \mathrm{~m}, \mathrm{C}_{1}$ generally ranges from 47 to $98 \%$ (vol.) and $\mathrm{CO}_{2}$ from 1 to $10 \%$ (vol.) of the total gas mixture, with the balance being air and an undetermined amount of $\mathrm{N}_{2}$. Average $\mathrm{C}_{1}$ concentrations appear to decrease slightly with depth whereas $\mathrm{CO}_{2}$ concentrations increase. $\mathrm{C}_{2}$ and the heavier hydrocarbon gases also increase in abundance with depth. Ratios of $\mathrm{C}_{1} / \mathrm{C}_{2}$ were high (averaging about 40,000 in the interval between 25 and $200 \mathrm{~m}$ sub-bottom) and decreased exponentially to about 4000 at $399 \mathrm{~m}$ depth. The trend of exponentially decreasing $\mathrm{C}_{1} / \mathrm{C}_{2}$ ratios with depth has been observed previously at a number of DSDP sites (Fig. 6). The very high ratios of $C_{1} / C_{2}$ indicate that the $C_{1}$ formed as a product of microbiological processes operating in these shallow sediments (Bernard et al., 1976). Superimposed on the microbial production of $C_{1}$ is the possible lowtemperature generation of the other hydrocarbon gases, which increase in concentration with increasing depth of burial. Thus these results reflect the effects of early diagenesis of organic material.

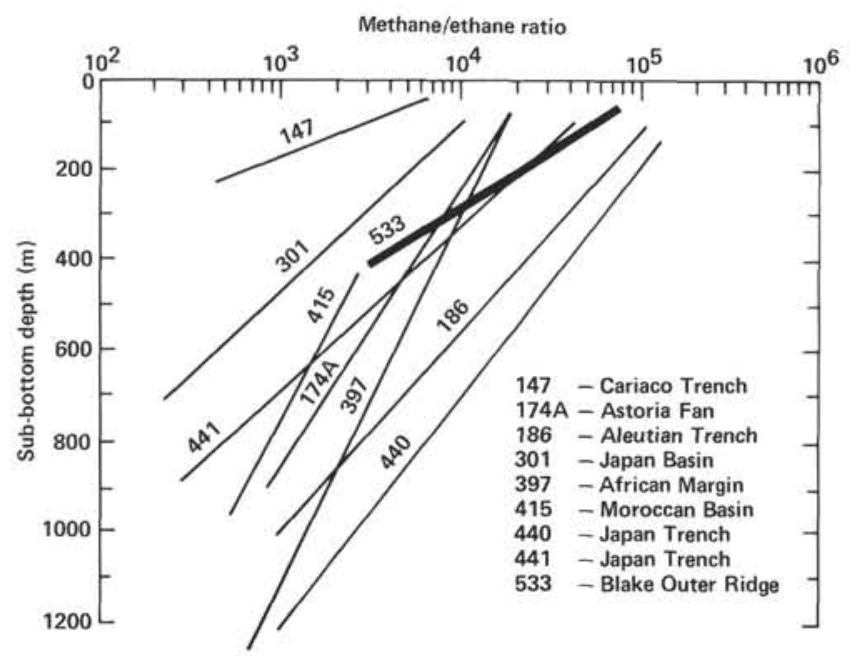

Figure 6. $C_{1} / C_{2}$ ratios versus sub-bottom depth of gases in sediments at many DSDP sites, including Site 533. (Except for Site 533, data are from Claypool [1976], Whelan and Sato [1980], and Galimov et al. [1980].)
The carbon isotopic composition of $\mathrm{C}_{1}$ and $\mathrm{CO}_{2}$ in the gas pockets has also been measured and is discussed in detail by Galimov and Kvenvolden (this volume). The $\delta^{13} C_{C_{1}}$ values (referred to the PDB standard) follow a systematic but nonlinear change with depth from about -94 to about -66 per mil. The $\delta^{13} \mathrm{C}_{\mathrm{CO}_{2}}$ values trend subparallel to the values for $\mathrm{C}_{1}$ and range from about -25 to -4 per mil. The light carbon isotopic composition of $\mathrm{C}_{1}$ and $\mathrm{CO}_{2}$ indicates that the $\mathrm{C}_{1}$ formed through microbiological reduction of $\mathrm{CO}_{2}$ from organic matter (Claypool and Kaplan, 1974). That this process is operative is supported by the observation that the organic matter in sediments at Site 533 has $\delta^{13} \mathrm{C}$ values ranging from -21 to -25 per mil (Brooks et al., this volume), and these values are similar to the $\delta^{13} \mathrm{C}_{\mathrm{CO}_{2}}$ values in the shallow sediments. Thus the molecular compositions of the hydrocarbon gases and the isotopic compositions of $\mathrm{C}_{1}$ and $\mathrm{CO}_{2}$ all indicate that microbial processes are responsible for the $\mathrm{C}_{1}$ and $\mathrm{CO}_{2}$ in these sediments.

In addition to analyses of gases in gas pockets, headspace analyses provided a means of measuring the composition of gas extracted from sediment at intervals down the core. Sampling did not depend on the formation of gas pockets, as required for the procedure where vacutainers were used. In the headspace method, gases were extracted from the sediment by vigorous shaking to partition sediment gas into a helium-filled headspace. Headspace analyses of core samples started near the sediment surface and continued downward to about 399 $\mathrm{m}$. Results and procedures are presented in the Site $\mathbf{5 3 3}$ report (this volume). These results provide a means of estimating the concentrations of gases remaining in the sediment after core recovery. Most of this gas probably is dissolved in the pore water; free gas, released during coring, is mostly lost. Figure 7 shows profiles with depth at Site 533 of concentrations of $\mathrm{C}_{1}$ and $\mathrm{CO}_{2}$ in milliliters per liter of wet sediment $(\mathrm{ml} / \mathrm{l})$ and of $\mathrm{C}_{2}$ and $\mathrm{C}_{3+}$ in microliters per liter of wet sediment $(\mu \mathrm{l} / \mathrm{l})$.

In Site 533 sediments, $\mathrm{C}_{1}$ and $\mathrm{CO}_{2}$ are the most abundant of the identified gases. In the uppermost $15 \mathrm{~m}$ of sediment, $\mathrm{C}_{1}$ concentrations are about $35 \mu \mathrm{l} / \mathrm{l}$, but by 22 $\mathrm{m}$ have increased to about $22 \mathrm{ml} / 1 . \mathrm{C}_{1}$ concentrations reach a maximum of $82 \mathrm{ml} / 1$ at about $40 \mathrm{~m}$ depth. From about 100 to $399 \mathrm{~m}, \mathrm{C}_{1}$ concentrations averaged about $19 \mathrm{ml} / 1$. That gas hydrates were present in this interval is not evident from the concentrations of $C_{1}$. Any gas hydrates that had been present likely would have decomposed and the gas lost before the samples were analyzed. Above $154 \mathrm{~m}$, the amount of $\mathrm{CO}_{2}$ found is less than 6 $\mathrm{ml} / \mathrm{l}$, and in deeper samples the recovered $\mathrm{CO}_{2}$ generally ranges in abundance from 6 to $21 \mathrm{ml} / 1$. Hydrocarbon gases larger than $C_{1}$ are also present in small amounts with total concentrations always less than $30 \mu \mathrm{l} / \mathrm{l} . \mathrm{C}_{2}$ through $\mathrm{C}_{4}$ hydrocarbons could be measured in all samples from a depth of 1.5 to $396 \mathrm{~m}$. $\mathrm{C}_{5}$ hydrocarbons could be detected at depths below about $32 \mathrm{~m}$, and $\mathrm{C}_{6}$ hydrocarbons could be detected below about $157 \mathrm{~m}\left(\mathrm{C}_{6}\right.$ hydrocarbons could not be identified in the gas from gas pockets because of contamination in the vacutainers used for recovery of gas samples from core liners). Concentrations of $\mathrm{C}_{2}$ and heavier hydrocarbons increase with 


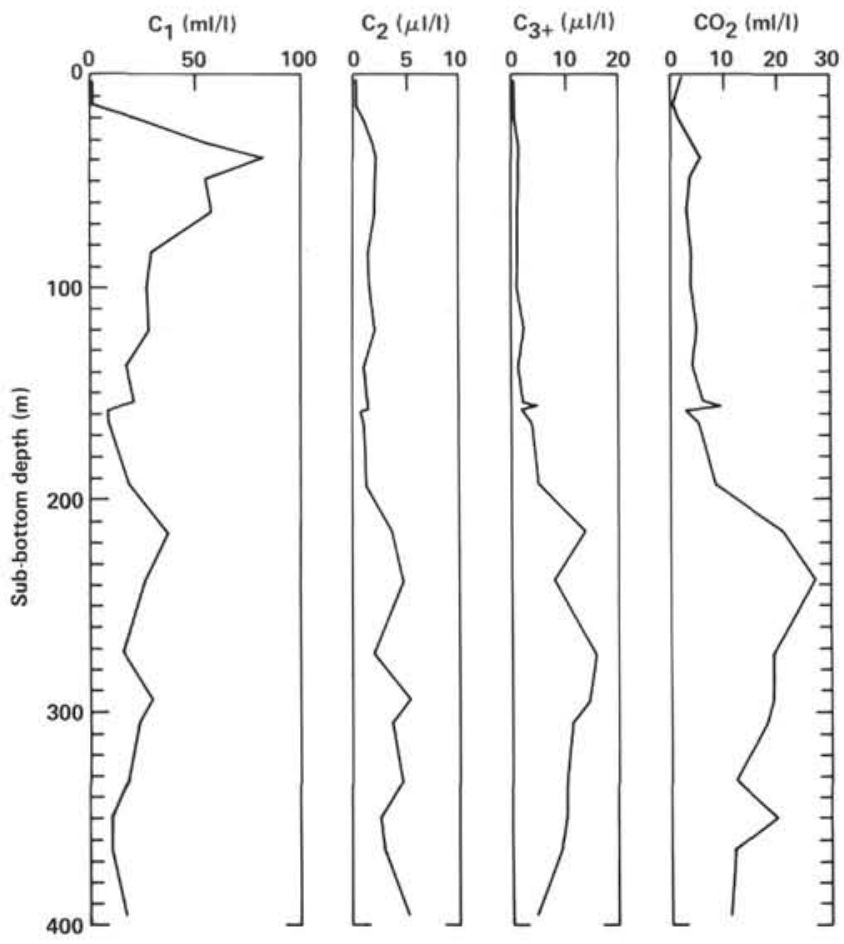

Figure 7. Concentration profiles with sub-bottom depth of $C_{1}, C_{2}$, $\mathrm{CO}_{2}$, and the sum of $\mathrm{C}_{3}, \mathrm{i}-\mathrm{C}_{4}, n-\mathrm{C}_{4}, \mathrm{i}-\mathrm{C}_{5}, \mathrm{i}-\mathrm{C}_{6}$, and $n-\mathrm{C}_{6}$, extracted into a helium headspace from sediments at Site 533 .

depth, a trend similar to that found for gases from gas pockets. The $\mathrm{C}_{1} / \mathrm{C}_{2}$ ratios decrease exponentially with depth, but the values are slightly lower than for gases from the gas pockets. These ratios range from about 35,000 to about 3000 over the interval from 20 to $396 \mathrm{~m}$. For samples from depths shallower than $20 \mathrm{~m}$, the $\mathrm{C}_{1}$ / $\mathrm{C}_{2}$ ratios range from 600 to 1900 . These lower values probably reflect the preferential loss of $\mathrm{C}_{1}$ by diffusion or oxidation in these shallow sediments.

Additional headspace analyses have been carried out, and these measurements plus carbon isotopic compositions of recovered $\mathrm{C}_{1}$ are discussed by Brooks et al. (this volume). The molecular and isotopic results affirm the results and trends just described. Thus all results support the idea that the $\mathrm{C}_{1}$ in these sediments is microbiologically generated and that organic matter is undergoing early diagenetic processes leading to increasing amounts of increasingly heavier hydrocarbons.

\section{OBSERVED GAS HYDRATES AT SITE 533}

Although the occurrence of gas in the first $399 \mathrm{~m}$ of sediment at Site 533 is well documented, as explained in the preceding section, none of the observations specifically indicated the presence of gas hydrates. Coring showed no unusual features from 0 to $152 \mathrm{~m}$ sub-bottom depth except for gas pockets, which were common in cores deeper than $50 \mathrm{~m}$. Below $152 \mathrm{~m}$, the following intervals contained disrupted sediment and evidence of frothing, suggesting the possibility of gas-hydrate decomposition: 152 to $155 \mathrm{~m}, 171$ to $190 \mathrm{~m}, 209$ to $218 \mathrm{~m}$, and 288 to $250 \mathrm{~m}$. Otherwise the sediment was semiconsolidated with little evidence of gas except occasional gas pockets. Beneath $250 \mathrm{~m}$, the sediment remained semiconsolidated to the bottom of the hole at $399 \mathrm{~m}$, with some disruptions and gas pockets but no obvious evidence of gas hydrates.

Direct evidence for gas hydrates was obtained from a single sample recovered from a sub-bottom depth of 238 $\mathrm{m}$. When Core 13 of Hole 533A was first recovered, the vent subassembly blew off as the core barrel was lowered to the deck, indicating the buildup of high gas pressure. A few centimeters-thick layer of frothy sediment, with matlike white crystals that disappeared quickly, was observed at $26 \mathrm{~cm}$ from the top of the first section of the core when the core was split (Fig. 8). Portions of this sample were immediately used for pressure and volume measurements.

Pressure developed during gas-hydrate decomposition was measured in a pressure device (Fig. 9) composed of a $22-\mathrm{cm}^{3}$ sample holder, a gauge, and a gas-sampling port with septum. Volume of the whole system was $\cong 25 \mathrm{~cm}^{3}$. A $10-\mathrm{cm}^{3}$ sample of the sediment containing gas hydrate was placed in the sample holder where it decomposed, yielding a pressure of $\cong 50 \mathrm{psi}$ at $\mathrm{O}^{\circ} \mathrm{C}$. Raising the temperature of the sample holder to $70^{\circ} \mathrm{C}$ increased the pressure to $\cong 70 \mathrm{psi}$. The increase in pressure was due to both further decomposition of the gas hydrate and the expansion of gas in the pressure device because of the increase in temperature. The volumetric expansion of the gas from the decomposing gas hydrate, calculated from the pressure and temperature measurements, was about 20 times the volume of pore fluid present in the sediment.

At the same time the pressure-measuring experiment was in progress, a second experiment directly measured the volume of gas released during gas-hydrate decomposition. The device for making this measurement was constructed from materials available aboard ship and consisted of a graduated cylinder and two plastic syringes (Fig. 10). In this device the volume of sediment as well as the volume of gas released could be measured by

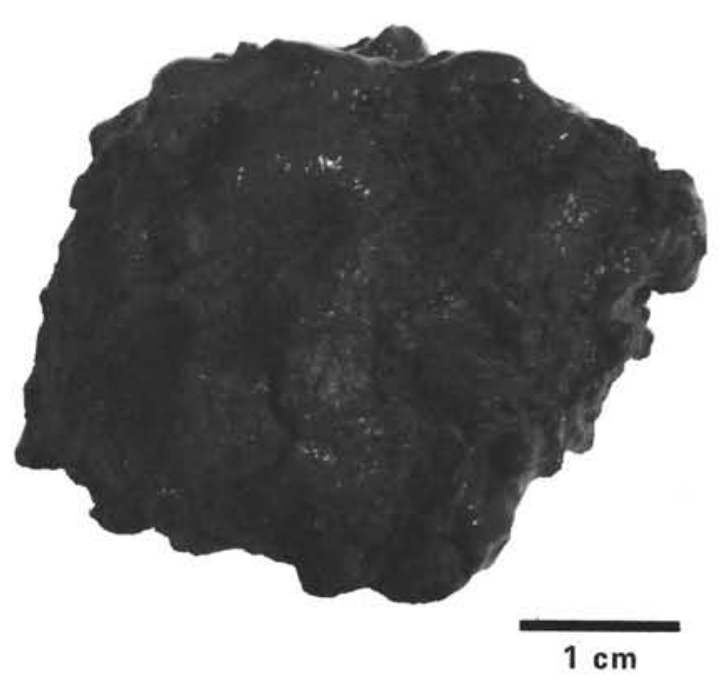

Figure 8. Sample of sediment containing gas hydrate recovered from a sub-bottom depth of $238 \mathrm{~m}$ at Site 533 . 


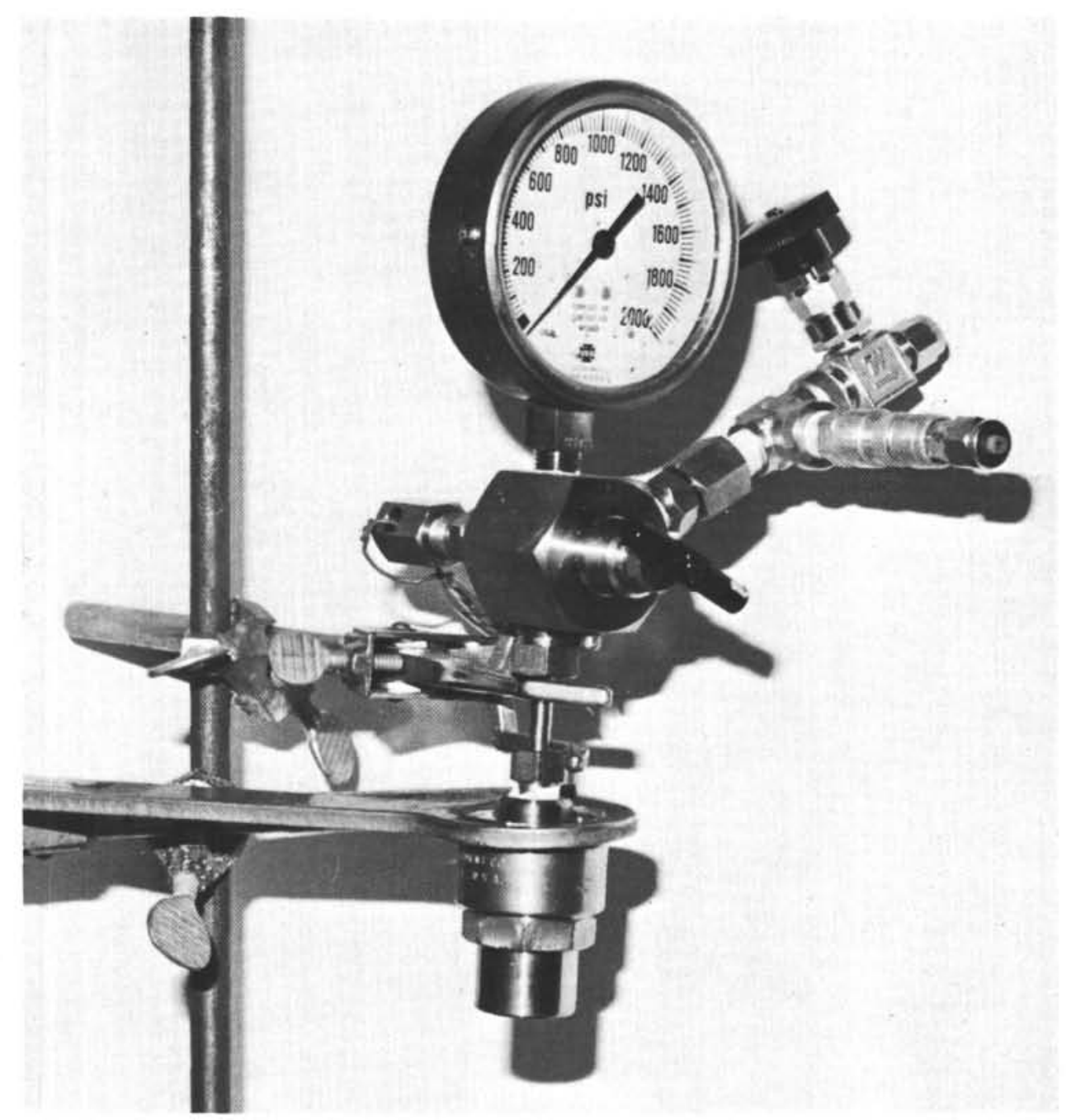

Figure 9. Pressure-measuring device from which it was determined that the decomposition of the gas hydrate produced about 20 volumes of gas to 1 volume of pore fluid. (A portion of this gas was removed through the septum, and the composition of the gas was determined [see Table 1].)

displacement of water. This simple device provided a measure of 13 volumes of gas to 1 volume of sediment, which calculated to about 20 volumes of gas to 1 volume of pore fluid.

Therefore, the results from both the pressure-measuring and the volume-measuring devices showed that upon decomposition the gas hydrate released a volume of gas approximately 20 times greater than the volume of pore fluid in the gas hydrate-containing sediment sample. This volume of gas released is at least a factor of 4 larger than the volume of gas that can be in solution in an equivalent volume of pore water at the pressure and temperature conditions of the original sample. Thus the volumetric expansion of 20:1 (volume of gas to volume of pore fluid) is strong evidence that a sample of gas hydrate had indeed been recovered, observed, and measured, because a gas hydrate is a gas concentrator.

A sample of gas resulting from gas-hydrate decomposition in the pressure device was analyzed by removing a portion of gas through the septum with a syringe and measuring the gas composition by gas chromatography. The results are shown in Table $1 . \mathrm{C}_{1}$ constituted about
$36 \%$ (vol.) of the gas in the device; most of the remaining gas, besides $\mathrm{CO}_{2}$ and probably $\mathrm{N}_{2}$, was air, because no provisions were taken to remove air after the sample of gas hydrate-containing sediment was placed in the pressure-measuring device. The $\delta^{13} \mathrm{C}_{\mathrm{c}_{1}}$ value of this gas is -70 per mil, a value similar to -69 per mil of $C_{1}$ from a nearby gas pocket (Galimov and Kvenvolden, this volume). Of interest is the relative distribution of the hydrocarbon gases. $\mathrm{C}_{1}, \mathrm{C}_{2}, \mathrm{C}_{3}$, and $\mathrm{i}-\mathrm{C}_{4}$ are present in significantly higher concentrations than $n-\mathrm{C}_{4}, \mathrm{i}-\mathrm{C}_{5}$, and $n-C_{5}$. This distribution contrasts with the distribution of hydrocarbon gases recovered from gas pockets in the cores (Fig. 11). The hydrocarbon gases from gas pockets do not show the abrupt decrease in concentrations of all molecules larger than $\mathrm{i}-\mathrm{C}_{4}$; that is, $n-\mathrm{C}_{4}, \mathrm{i}-\mathrm{C}_{5}$, and $n-\mathrm{C}_{5}$.

The distribution of hydrocarbons from the decomposing gas hydrate may be explained on the basis of the sizes of the cages in the gas hydrate structure. As discussed in the introduction, hydrocarbon gases larger than $\mathrm{i}-\mathrm{C}_{4}$ cannot be included in either Structure I or II hydrates (Hand et al., 1974). The molecular distribution of hydrocarbons from the gas hydrate-containing sediment 


\section{K. A. KVENVOLDEN, L. A. BARNARD}

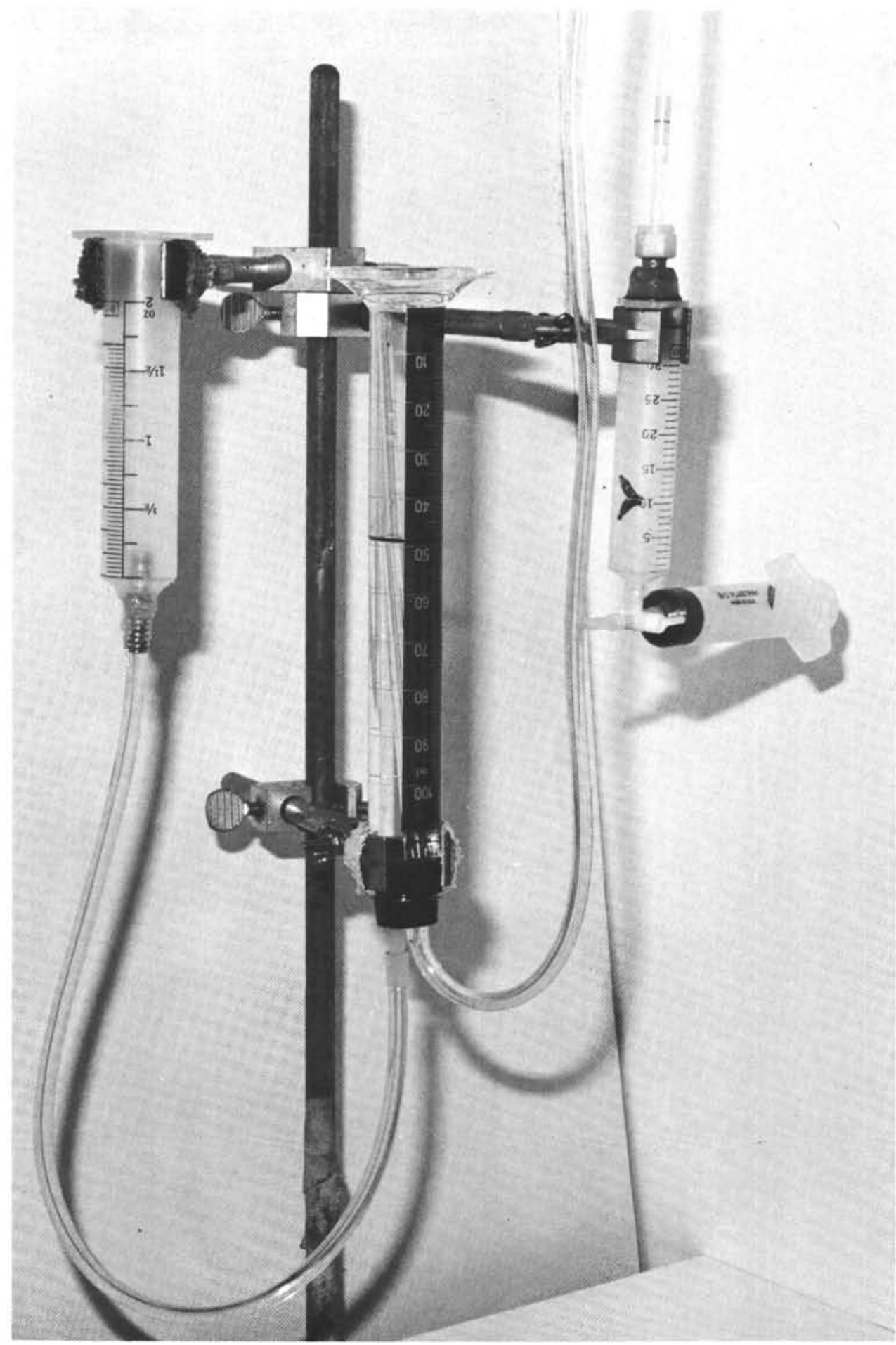

Figure 10. This volume-measuring device determined that the volume of gas released during gas-hydrate decomposition was about 20 times larger than the volume of pore fluid.

sample seems to follow a pattern predicted from gas-hydrate crystallography. Our results suggest that Structure I gas hydrate was present, because $\mathrm{C}_{1}$ was the dominant hydrocarbon; $\mathrm{C}_{2}$ would also fit in the cages of Structure I (Fig. 1). $\mathrm{C}_{3}$ and i-C $\mathrm{C}_{4}$ were present in concentrations of about 2 ppm (vol.) whereas the larger hydrocarbon gases $n-\mathrm{C}_{4}, \mathrm{i}-\mathrm{C}_{5}$, and $n-\mathrm{C}_{5}$ were present in amounts less
Table 1. Concentrations of gases recovered from decomposed gas hydrate.

\begin{tabular}{ccccccccc}
\hline $\begin{array}{c}\mathrm{C}_{1} \\
(\%)\end{array}$ & $\begin{array}{c}\mathrm{C}_{2} \\
(\mathrm{ppm})\end{array}$ & $\begin{array}{c}\mathrm{C}_{3} \\
(\mathrm{ppm})\end{array}$ & $\begin{array}{c}\mathrm{i}-\mathrm{C}_{4} \\
(\mathrm{ppm})\end{array}$ & $\begin{array}{c}n-\mathrm{C}_{4} \\
(\mathrm{ppm})\end{array}$ & $\begin{array}{c}\mathrm{i}-\mathrm{C}_{5} \\
(\mathrm{ppm})\end{array}$ & $\begin{array}{c}n-\mathrm{C}_{5} \\
(\mathrm{ppm})\end{array}$ & $\begin{array}{c}\mathrm{CO}_{2} \\
(\%)\end{array}$ & ${ }^{{ }^{13} \mathrm{C}_{\mathrm{C}_{1}}}$ \\
\hline 36 & 123 & 2 & 2 & 0.06 & 0.15 & 0.13 & 0.5 & -70 \\
\hline
\end{tabular}


Concentrations relative to $C_{2}=100$

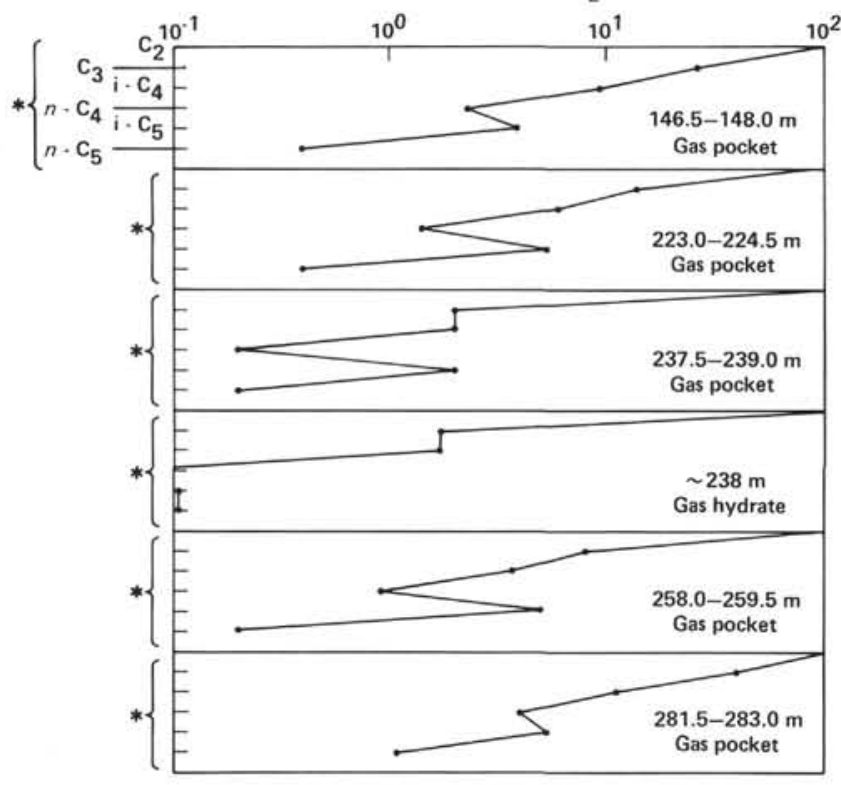

Figure 11. Comparison of the hydrocarbon composition of gas recovered from a sediment containing obvious gas hydrates (Fig. 8) and gas removed from gas pockets within various intervals in the same core. (The concentrations are normalized to ethane $=100$. Gas from a pocket in the interval from 237.5 to $239.0 \mathrm{~m}$ has the same relative compositions of $\mathrm{C}_{2}, \mathrm{C}_{3}$, and i- $\mathrm{C}_{4}$ as gas from the gas hydrate found within the same interval at $238 \mathrm{~m}$; however, the gas in the pocket has higher concentrations of $n-\mathrm{C}_{4}, \mathrm{i}-\mathrm{C}_{5}$, and $n-\mathrm{C}_{5}$ than does gas from the gas hydrate.)

than 1 ppm (vol.). Thus a few crystals of Structure II gas hydrate may have been present to account for the small amounts of $\mathrm{C}_{3}$ and $\mathrm{i}-\mathrm{C}_{4}$ found. The larger molecules, $n-\mathrm{C}_{4}, \mathrm{i}-\mathrm{C}_{5}$, and $n-\mathrm{C}_{5}$, are in such low concentrations perhaps because they were effectively excluded from the gas-hydrate structures. The results of this experiment imply that much of the gas removed from cores at Site 533 was not in hydrate form, because the relative distribution of hydrocarbon gases from the gas pockets did not show the abrupt decrease in concentrations of hydrocarbons larger than $\mathrm{i}-\mathrm{C}_{4}$.

How the gas hydrates are distributed in the hemipelagic sediment at Site 533 is not known. Sediment is disrupted and sometimes frothy in the interval between 152 and $250 \mathrm{~m}$, suggesting that fine-grained gas hydrates possibly had been present but had decomposed during the coring operations. Recovery of the one sample of gas hydrate-containing sediment from $238 \mathrm{~m}$ was fortuitous. Apparently, the gas hydrates at this site do not form a massive, solid layer, as could be inferred from seismic records (Fig. 3). Much of the gas hydrate may be finely dispersed throughout the sediment, so that upon decomposition there was little evidence of sediment disruption except in the interval between 152 and $250 \mathrm{~m}$ where the gas hydrates may have been more concentrated. Figure 12 shows the relationship between the gas hydrate at Site 533 and the natural gas hydrate phase boundary. The geothermal gradient intersects the phase boundary near the inferred base of the gas hydrate ( $\sim 600 \mathrm{~m}$ sub-bottom), which correlates with the BSR (Fig. 3).

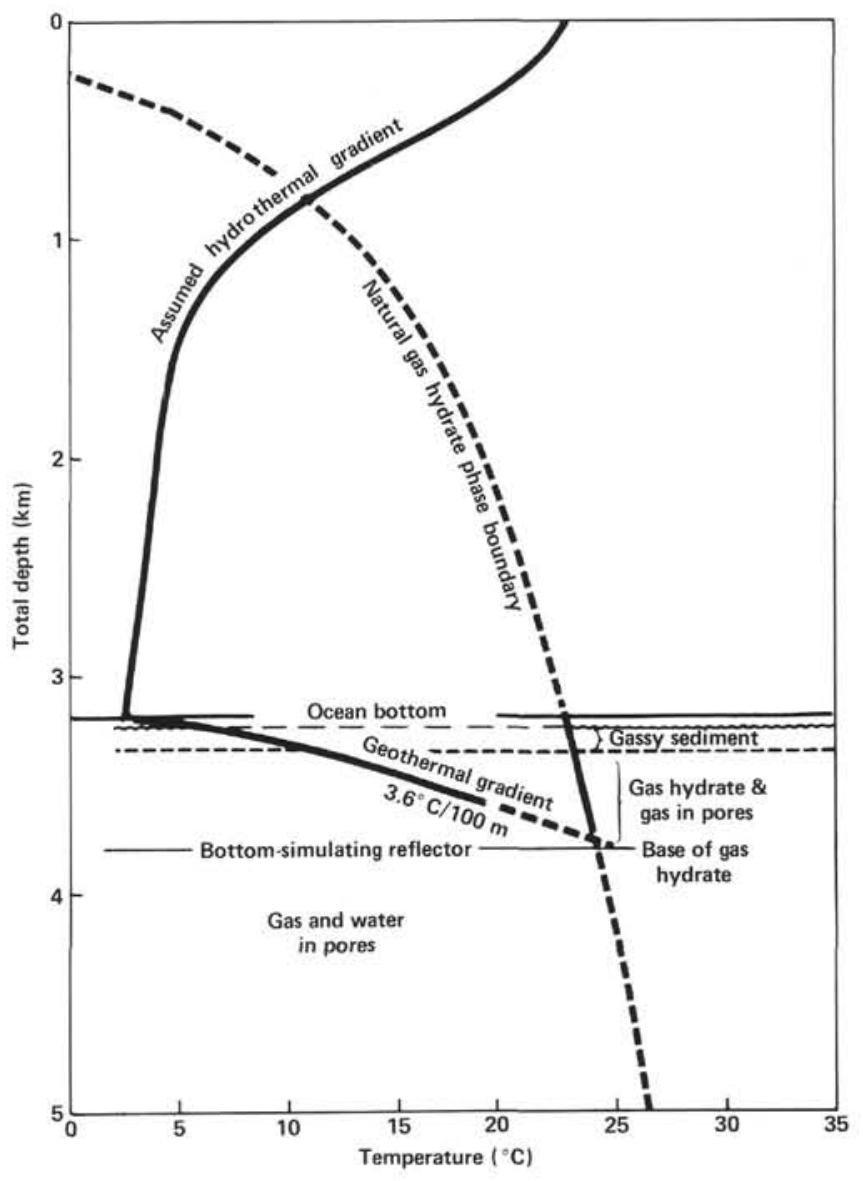

Figure 12. Diagrammatic section relating the zone of gas hydrates at Site 533 to the natural gas hydrate phase boundary, an assumed hydrothermal gradient, and the measured geothermal gradient, which is discussed in the Site 533 report (this volume).

\section{ANALYSES OF SAMPLES RECOVERED AT IN SITU PRESSURES}

A pressure core barrel (PCB) (Larsen et al., 1980) was deployed five times at Site 533 (Table 2) to test for gas hydrates. Details of these experiments are discussed by Kvenvolden, et al. (this volume). Three cores were recovered at approximately in situ pressure between 27.5 and $32.3 \mathrm{MPa}$. PCB-4 had only $10.3 \mathrm{MPa}$ pressure due to a leaking assembly; and PCB-2, which had no pressure because of a missing plug, recovered only a short unpressurized core. Pressurized sediment cores were intermittently degassed at varying intervals of time, and portions of the gas were collected for analyses by drawing the gas through a transfer manifold and high-pressure regulator into steel sampling cylinders. Gas was released intermittently from PCB-1, PCB-3, and PCB-5 at intervals spanning about $3 \mathrm{hr}$. PCB-4 was vented immediately. The pressure release curves from PCB-1, PCB-3, and PCB-5 showed some pressure recovery after partial degassing. This behavior suggested that gas hydrates were present, but inefficient transfer of gases coming out of solution could also produce similar results. Pressure release curves are presented in Kvenvolden et al. (this volume) and Brooks et al. (this volume). 
Gas samples were collected during the degassing of PCB-3, PCB-4, and PCB-5; no gas samples could be collected from PCB-1, because the gas came out as a slurry of mud, or from PCB-2, because there was no pressurized core. This lack of gas samples was disappointing, because these PCB cores came from sediment intervals $(152.0-164.5 \mathrm{~m}$ and $247.0-254.8 \mathrm{~m}$ ) where there was visible evidence of the possible presence of gas hydrates, as discussed previously. Gas samples from PCB-3, PCB4 , and $\mathrm{PCB}-5$ were analyzed by gas chromatography, and $\delta^{13} \mathrm{C}_{\mathrm{C}_{1}}$ values were measured (see Brooks et al., this volume). The $C_{1} / C_{2}$ ratios and the $\delta^{13} C_{C_{1}}$ values did not vary significantly during degassing. Averages of the $C_{1} /$ $\mathrm{C}_{2}$ ratios and the $\delta^{13} \mathrm{C}_{\mathrm{C}_{1}}$ values are similar to averages obtained from gases recovered directly from gas pockets in unpressurized cores from adjacent sediment intervals (Table 2). Although $C_{1} / C_{2}$ ratios and $\delta^{13} C_{C_{1}}$ remain about the same during degassing, the relative amounts of $\mathrm{C}_{3}, \mathrm{i}-\mathrm{C}_{4}, n-\mathrm{C}_{4}, \mathrm{i}-\mathrm{C}_{5}, n-\mathrm{C}_{5}$, and $\mathrm{CO}_{2}$ increase (Brooks et al., this volume).

The results from the pressure core barrel experiments provide tentative but equivocal evidence for the presence of gas hydrates at Site 533. The amount of gas hydrate indicated is very small, and this conclusion agrees with the visual evidence for gas hydrates at this site.

\section{EFFECTS OF GAS HYDRATES ON PORE-WATER CHEMISTRY}

The shipboard interstitial water sampling program included measurements of $\mathrm{pH}$, alkalinity, salinity, chlorinity, calcium, and magnesium in pore water squeezed from sediments of Holes 533 and 533A. Results are tabulated in the Site 533 report (this volume). Trends in the concentrations of chlorinity and salinity are presented in Figure 13, where depletion in these two parameters with depth is clearly shown. Sediment obtained during the first $168 \mathrm{~m}$ were cored with the hydraulic piston core (Hole 533), and pore-water contamination by seawater was minimized. On the other hand, pore water obtained from sediments recovered by rotary coring (Hole 533A) may have been contaminated with seawater, resulting in the abrupt shift in chlorinity and salinity values at about $150 \mathrm{~m}$.

Depletion of chloride content and salinity with depth may be due to the presence of gas hydrates. During gashydrate formation, water molecules will be withdrawn from solution to form the water clathrate. This process should lead to increased chlorinity and salinity in any water not involved in gas-hydrate formation. If this

Table 2. Results from pressure core barrel (PCB) sampling at Site 533.

\begin{tabular}{|c|c|c|c|c|c|c|c|c|}
\hline \multirow[b]{2}{*}{$\begin{array}{l}\text { PCB } \\
\text { No. }\end{array}$} & \multirow{2}{*}{$\begin{array}{l}\text { Sub-bottom } \\
\text { depth interval } \\
\text { (m) }\end{array}$} & \multirow{2}{*}{$\begin{array}{l}\text { Amount } \\
\text { cored } \\
(\mathrm{m})\end{array}$} & \multirow[b]{2}{*}{$\begin{array}{c}\text { Pressure } \\
(\mathrm{MPa})\end{array}$} & \multicolumn{2}{|c|}{$\mathrm{C}_{1} / \mathrm{C}_{2}$ (avg.) } & \multicolumn{3}{|c|}{${ }^{8{ }^{13}} \mathrm{C}_{\mathrm{C}_{1}}$} \\
\hline & & & & $\mathrm{PCB}^{\mathrm{c}}$ & $\underset{\text { pockets }}{\text { Gas }}$ & $\mathrm{PCB}^{\mathrm{C}}$ & $\begin{array}{l}\text { Sediment } \\
\text { extraction }{ }^{\mathrm{c}}\end{array}$ & $\begin{array}{c}\text { Gas } \\
\text { pockets }\end{array}$ \\
\hline PCB-1 & $152.0-154.5$ & 6.4 & 27.5 & n.d. ${ }^{b}$ & 42000 & n.d. & -71 & -71 \\
\hline PCB-2 & $247.0-254.8$ & $1.6^{\mathrm{a}}$ & 0 & n.d. & 20000 & n.d. & -68 & -67 \\
\hline PCB-3 & $332.5-340.3$ & 6.1 & 32.3 & 6000 & 9000 & -66 & -64 & -67 \\
\hline PCB-4 & $361.0-368.8$ & 6.1 & 10.3 & 5400 & 3800 & -64 & -64 & -66 \\
\hline PCB-5 & $392.2-399.0$ & 6.2 & 30.2 & 4100 & 4100 & -69 & -66 & -66 \\
\hline
\end{tabular}

water is free to migrate toward the sediment/water interface and escape into the seawater, the water remaining in the sediment, when measured, will be a mixture composed in part of pure water derived from gas-hydrate decomposition. This dilution with pure water will decrease the measured chlorinity and salinity in sediments where there are gas hydrates. At Site 533 chloride values decrease from $19.5 \%$ at the sediment surface to a minimum of $17.3 \%$ at about $300 \mathrm{~m}$. Salinity values decrease from 35 to $31.5 \%$ over the same sediment interval. Therefore the $2 \%$ depletion in chloride content and the $3.5 \%$ depletion in salinity may be due to gas hydrates in these sediments. Water recovered from the sediment sample that was used in the pressure-measuring device described earlier had an estimated salinity of about $11 \%$. This anomalous low value may be attributed to the fact that this sediment sample contained a significant concentration of gas hydrate.

Other evidence supports the observations of decreased chlorinity and salinity in sediments of the Blake Outer Ridge. Sayles et al. (1972), for example, observed chloride and salinity depletions in interstitial water samples collected at Sites 102, 103, and 104 (Fig. 4) of Leg 11. At these sites they observed a 1 to about $4 \%$ depletion in chloride and a 4 to about $8 \%$ odepletion in salinity with depth. No mechanistic interpretations of these observed depletions was given.

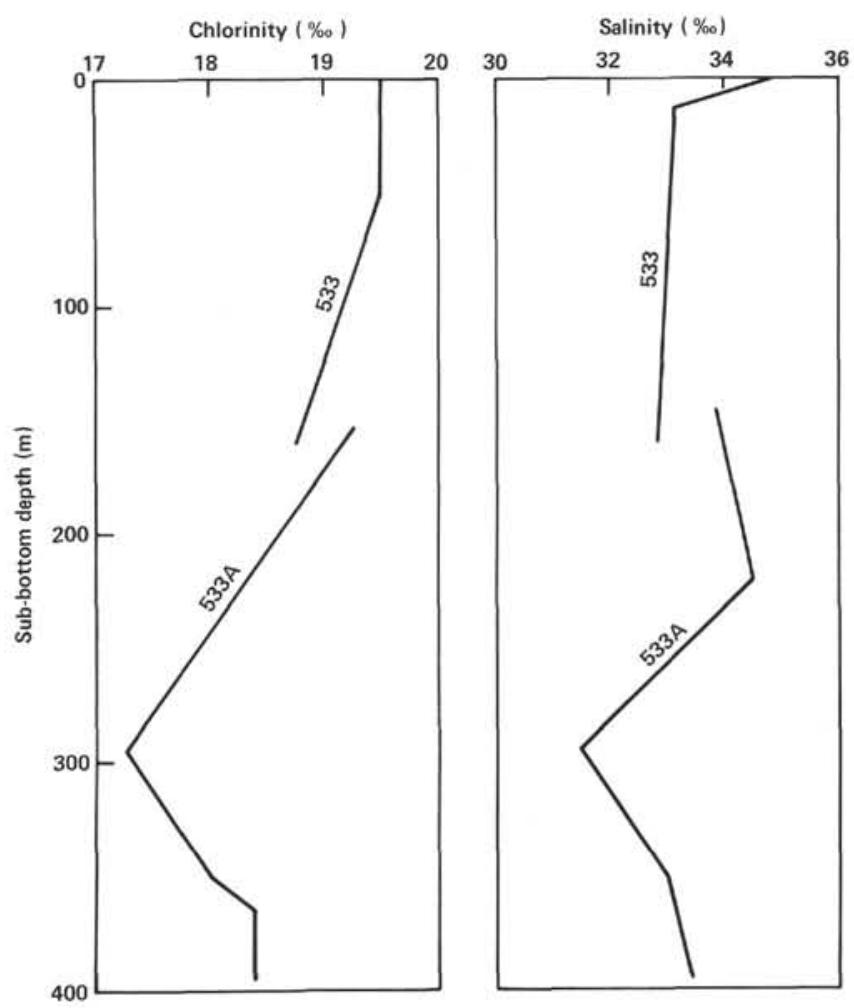

Figure 13. Trends of chlorinity and salinity with sub-bottom depths at Site 533. (The values for pore waters from sediments recovered by rotary drilling of Hole 533A are displaced relative to values for pore waters from sediments recovered by piston core, probably because of contamination by seawater. Tabulation of data appears in the Site 533 report, this volume.) 
Recent studies of interstitial water chemistry of samples from Leg 67, offshore Guatemala, show marked depletion of chloride content ( 6 and $10 \%$ ) and of salinity (about 18 and 17\%) with depth at Sites 496 and 497, respectively, where gas hydrates were found (Harrison et al., 1982). Little or no change in chloride was observed at sites where gas hydrates were absent. Thus the evidence strongly suggests that the presence of hydrates influences pore-water chemistry. This possible correlation of chloride and salinity depletion with the occurrence of gas hydrates may be useful in the identification of sediments where gas hydrates are, or have been, present. In the recovery of gas hydrate-containing sediment, decomposition of the gas hydrate often obscures the evidence by which the gas hydrate can be identified. The chloride and salinity depletions may provide clues in sediments where gas hydrates occur but cannot be directly observed.

\section{FORMATION OF MARINE GAS HYDRATES AT SITE 533}

Three lines of evidence lead to the conclusion that gas hydrates in sediments at Site 533 on the Blake Outer Ridge are derived through microbiological processes and not through thermogenic processes. First, although the hydrocarbon gas mixture found in these sediments contains compounds at least as large as $\mathrm{C}_{6}$, more than $99.9 \%$ of these hydrocarbons is $C_{1}$. Thus the mixture is a very dry natural gas with composition that suggests either a biogenic or metagenic source (Hunt, 1979). Because this gas occurs in very shallow sediments far removed from sources of heat capable of generating metagenic $C_{1}$, the $C_{1}$ found is most likely biogenic. Second, the carbon isotopic composition of $\mathrm{C}_{1}$ ranges from about -66 to -94 per mil; $\delta^{13} C_{C_{1}}$ values in this range, and particularly the lighter values, are indicative of biogenic $C_{1}$ (Fuex, 1977). Third, the carbon isotopic composition of $\mathrm{CO}_{2}$ subparallels that of $\mathrm{C}_{1}$, suggesting that $\mathrm{CO}_{2}$ is the main precursor of $\mathrm{C}_{1}$. The $\delta^{13} \mathrm{C}_{\mathrm{CO}_{2}}$ values indicate that the $\mathrm{CO}_{2}$ probably was derived initially from organic matter that has $\delta^{13} \mathrm{C}$ values from -21 to -25 per mil, and this range of $\delta^{13} \mathrm{C}$ values was actually found for the organic matter in sediments at Site 533 (Brooks et al., this volume). Thus we believe the concurrence of evidence points to a biogenic source for $C_{1}$ and the process of $\mathrm{C}_{1}$ formation involves bacterial alteration of organic matter buried in the sediments.

$\mathrm{C}_{1}$ production in sediment requires a minimum of about $0.5 \%$ organic carbon and pore water depleted in dissolved oxygen and sulfate (Claypool and Kaplan, 1974). At Site 533 the organic carbon content of the sediments more shallow than $150 \mathrm{~m}$ averages about $0.5 \%$, but below this depth the organic carbon content increases. From 215 to $399 \mathrm{~m}$, the organic carbon content is generally greater than $1 \%$ and reaches values as high as $1.4 \%$ (Fig. 14). Thus there appears to be sufficient organic matter to support $C_{1}$ generation. We did not measure the pore-water content of oxygen, but sulfate was depleted in the pore water of sediments from subbottom depths greater than $14 \mathrm{~m}$ (Claypool and Threlkeld, this volume). The rapid increase in concentrations

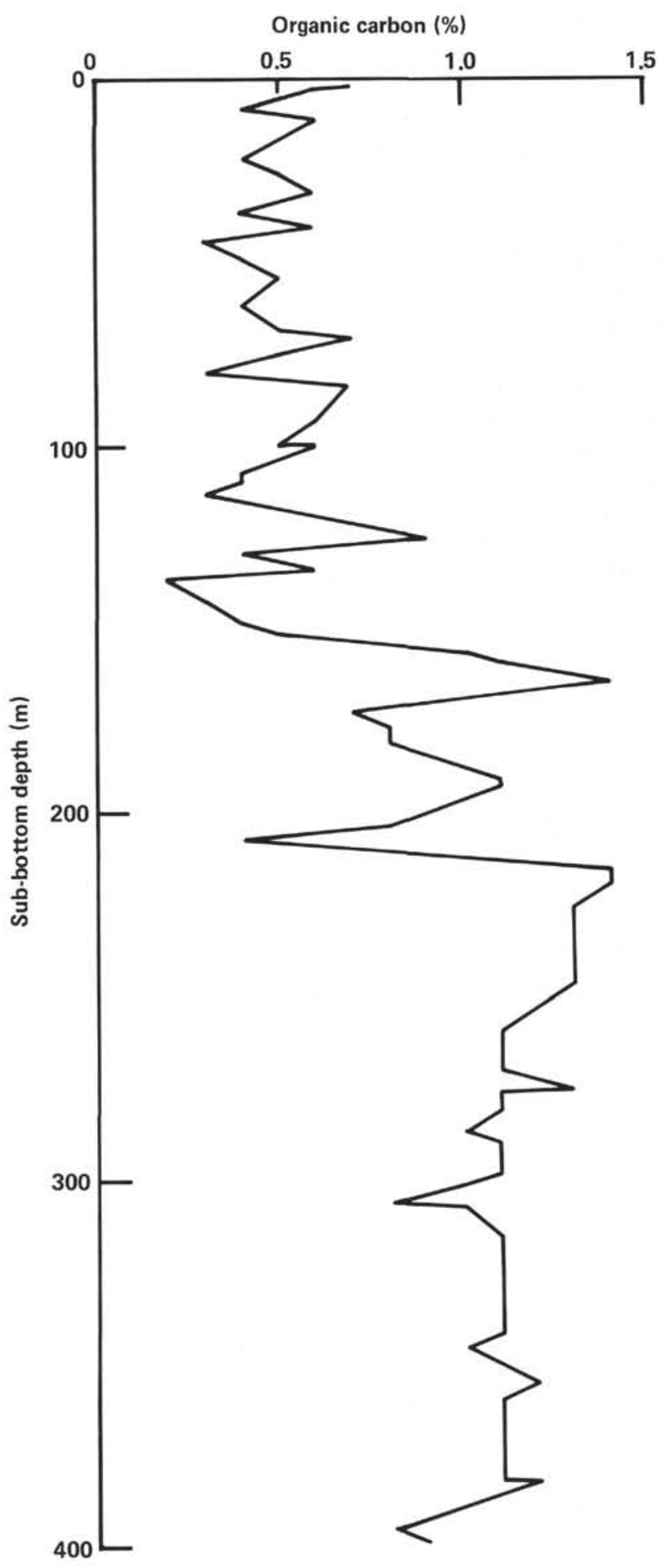

Figure 14. Profile of organic carbon versus sub-bottom depths at Site 533. (The values increase at about $158 \mathrm{~m}$ where an unconformity separates late Pliocene from early Pleistocene sediments. Tabulation of data appears in Appendix I.)

of $\mathrm{C}_{1}$ at depths between 12 and $40 \mathrm{~m}$ sub-bottom (Fig. 7) indicates that sulfate reduction has ceased and that $C_{1}$ production has begun in that sediment interval.

High rates of sedimentation have doubtlessly promoted the deposition and preservation of organic mat- 
ter at Site 533 where deeper sediments of the middle Pliocene were deposited at $21 \mathrm{~cm} / 10^{3} \mathrm{yr}$. and the upper sediments of the late Pleistocene and Holocene at $7 \mathrm{~cm}$ / $10^{3} \mathrm{yr}$. A very low sedimentation rate of $1 \mathrm{~cm} / 10^{3} \mathrm{yr}$., however, occurred between the latest Pliocene to earliest Pleistocene, implying sediment bypassing and erosion leading to an unconformity at $158 \mathrm{~m}$ sub-bottom. The sedimentological history at this site is detailed in the Site 533 report (this volume).

The formation of gas hydrates in sediments of the Blake Outer Ridge seems to follow a model for the origin of gas hydrates from biogenic $C_{1}$ that has been outlined by Kvenvolden and Barnard (in press) following ideas expressed earlier by Claypool and Kaplan (1974) and Rice and Claypool (1981). At the Blake Outer Ridge high rates of sedimentation have ensured the deposition of sufficient organic matter for $\mathrm{C}_{1}$ production. An ecological succession has been established in which metabolic processes vary with time and with depth in the sediments. Two biochemical zones have resulted: an upper aerobic zone overlying an anaerobic zone. Within the deeper anaerobic zone a region of sulfate reduction overlies a region of carbonate reduction and $\mathrm{C}_{1}$ production. Carbonate reduction is the favored mechanism of biogenic $C_{1}$ production; it probably accounts for most of the $\mathrm{C}_{1}$ produced here, as suggested by the carbon isotopic compositions of $\mathrm{C}_{1}$ and $\mathrm{CO}_{2}$ (Galimov and Kvenvolden, this volume; Claypool and Threlkeld, this volume), although other pathways for $\mathrm{C}_{1}$ production are available (Rice and Claypool, 1981).

After the ecological succession was established, the biochemical zones moved upward with time as new sediment was deposited at the sediment/water interface from contour-following currents. These biochemical and geological processes took place under pressure and temperature conditions suitable for gas-hydrate stability (Fig. 2 ), and sufficient $C_{1}$ was generated from an adequate supply of organic matter to form gas hydrates. $C_{1}$ production began in the zone of carbonate reduction at sediment depths below the zone of sulfate reduction, between 15 and $40 \mathrm{~m}$ sub-bottom. $\mathrm{C}_{1}$ generation was sufficiently rapid to overcome its loss by diffusion; $\mathrm{C}_{1}$ concentrations increased to exceed pore-water saturation levels, and gas hydrates formed. The hydrostatic pressures due to the overlying water column of $3184 \mathrm{~m}$ affected the solubility of $\mathrm{C}_{1}$ and influenced the amount of $\mathrm{C}_{1}$ required for the formation of gas hydrates. The zone of gas hydrate thickened until its base reached a subbottom depth of about $600 \mathrm{~m}$, where temperatures of about $25^{\circ} \mathrm{C}$ made the gas hydrate unstable. In this region free methane can occur, but it may have migrated back into the overlying zone of gas-hydrate stability.

This model of gas-hydrate formation contrasts with other ideas that most gas hydrates form from gas that has migrated from below into the zone of gas-hydrate stability. Upward migration of $C_{1}$ from deeper parts of the sedimentary section has been suggested for the formation of gas hydrates of the Blake Outer Ridge (Lancelot and Ewing, 1972; Dillon et al., 1980). Upward migration of $\mathrm{C}_{1}$ would be particularly attractive if a source of $C_{1}$ from thermal alteration of deeply buried organic matter were available, but on the Blake Outer Ridge such a source is not obvious. Furthermore, the molecular composition of the hydrocarbons and the isotopic composition of $\mathrm{C}_{1}$ in sediments at Site 533 indicate that $C_{1}$ is biogenic and not thermogenic. Of course, biogenic $C_{1}$ could be involved in the migration process from below the zone of gas hydrate stability, but this source would be limited by the lack of significant biologic activity in the deeply buried sediment. Our geochemical observations favor a biologic origin for $\mathrm{C}_{1}$ and oppose gas migration from depths as an important process in gas-hydrate formation in sediments of the Blake Outer Ridge.

\section{RESOURCE IMPLICATIONS OF GAS HYDRATES OF THE BLAKE OUTER RIDGE}

Seismic evidence based on the widespread occurrence of a BSR (Dillon et al., 1980) implies that gas hydrates are present over about $80,000 \mathrm{~km}^{2}$ of the Blake Outer Ridge (Fig. 4). Such an extensive occurrence of gas hydrates furthermore implies that significant amounts of $\mathrm{C}_{1}$ are present in the shallow sediments of this area. Our studies show that $\mathrm{C}_{1}$ is indeed abundant in these sediments. These fine-grained, hemipelagic sediments probably have very low permeability. The low permeability coupled with the apparent dispersed nature of gas hydrates within the sediments leads us to the conclusion that it would be difficult, if not impossible, to produce this gas even if the gas hydrates could be decomposed in situ because the gas would not migrate to production wells. If these gas hydrates form a permeability barrier, as suggested by the BSR, then gas may collect beneath this horizon. But even this gas would not be readily producible, because permeable reservoir sediments probably are not present. In addition, approximately $3000-\mathrm{m}$ water depth in this area poses problems for current production technology, although in the future this water depth will probably not be a limiting factor. Although gas hydrates are present in sediments of the Blake Outer Ridge, they probably do not constitute a future source of readily available natural gas, at least in the region of Site 533.

\section{ACKNOWLEDGMENTS}

We thank the individuals of the DSDP shipboard staff for their help during the sampling procedures, especially $\mathrm{Mr}$. Kenneth A. Thompson, whose care for the shipboard organic geochemistry laboratory made it a superb facility for the analytical work described in this paper. Research support for shorebased studies at Texas A\&M University was provided by the Gas Research Institute Grant 50 81363-0460 and the office of Naval Research Grant N00014-80-C-0113. This paper has been critically reviewed by G. E. Claypool and W. P. Dillon, whom we thank for their help.

\section{REFERENCES}

Bernard, B. B., Brooks, J. M., and Sackett, W. M., 1976. Natural gas seepage in the Gulf of Mexico. Earth Planet. Sci. Lett., 31:48-54.

Bryan, G. M., 1974. In situ indications of gas hydrates. In Kaplan, I. R. (Ed.), Natural Gases in Marine Sediments: New York (Plenum), pp. 298-308.

Claypool, G. E., 1976. Manual in Pollution Prevention and Safety. Joides Journal, 1(4):C7a.

Claypool, G. E., and Kaplan, I. R., 1974. The origin and distribution of methane in marine sediments. In Kaplan, I. R., (Ed.), Natural Gases in Marine Sediments: New York (Plenum), pp. 94-129. 
Claypool, G. E., Presley, B. J., and Kaplan, I. R., 1973. Gas analysis of sediment samples from Legs 10,11, 13, 14, 15, 18 and 19. In Creager, J. S., Scholl, D. W., et al., Init. Repts. DSDP, 19: Washington (U.S. Govt. Printing Office), 879-884.

Davidson, D. W., 1973. Clathrate hydrates. In Franks, F. (Ed.), Water, A Comprehensive Treatise, 2, Water in Crystalline Hydrates, Aqueous Solutions of Simple Nonelectrolytes: New York (Plenum), pp. 115-234.

Davidson, D. W., El-Defrawy, M. K., Fuglem, M. O., and Judge, A. S., 1978. Natural gas hydrates in northern Canada. Proc., Int. Conf. Permafrost 3rd, 1:937-943.

Dillon W. P., Grow, J. A., and Paull, C. K., 1980. Unconventional gas hydrate seals may trap gas off southeast U.S. Oil Gas J., 78(1): 124-130.

Ewing, J. I., and Hollister, C. D., 1972. Regional aspects of deep sea drilling in the western North Atlantic. In Hollister, C. D., and Ewing, J. I., et al., Init. Repts. DSDP, 11: Washington (U.S. Govt. Printing Office), 951-973.

Fuex, A. N., 1977. The use of stable carbon isotopes in hydrocarbon exploration. J. Geochem. Explor., 7:155-188.

Galimov, E. M., Chinyonov, V. A., and Ivanov, Ye. N., 1980. Isotopic composition of methane carbon and the relative content of the gaseous hydrocarbons in the deposits of the Moroccan Basin of the Atlantic Ocean (Deep Sea Drilling Project Sites 415 and 416). In Lancelot, Y., Winterer, E. L., et al., Init. Repts. DSDP, 50: Washington (U.S. Govt. Printing Office), 615-622.

Hand, J. H., Katz, D. L., and Verma, V. K., 1974. Review of gas hydrates with implication for ocean sediments. In Kaplan, I. R. (Ed.), Natural Gases in Marine Sediments: New York (Plenum), pp. 179-194.

Harrison, W. E., Hesse, R., and Gieskes, J. M., 1982. Relationship between sedimentary facies and interstitial water chemistry of slope, trench and Cocos Plate sites from the Middle America Trench transect, active margin off Guatemala. In Aubouin, J., von Huene, R., et al., Init. Repts. DSDP, 67: Washington (U.S. Govt. Printing Office), 603-615.

Hitchon, B., 1974. Occurrence of natural gas hydrates in sedimentary basins. In Kaplan, I. R. (Ed.), Natural Gases in Marine Sediments: New York (Plenum), pp. 195-225.

Hunt, J. M., 1979. Petroleum Geochemistry and Geology: San Francisco (W. H. Freeman).

Katz, D. L., Cornell, D., Kobayashi, R., Poettmann, F. H., Vary, J. A., Elenblass, J. R., and Weinaug, C. F., 1959. Handbook of Natural Gas Engineering: New York (McGraw-Hill).

Kvenvolden, K. A., and Barnard, L. A., in press. Hydrates of natural gas in continental margins. Proceedings of Hedberg Conference: Tulsa (Am. Assoc. Pet. Geol.).

Kvenvolden, K. A., and McMenamin, M. A., 1980. Hydrates of natural gas: a review of their geologic occurrence. U.S. Geol. Surv. Circ., 825:1-11.
Lancelot, Y., and Ewing, J. 1., 1972. Correlation of natural gas zonation and carbonate diagenesis in Tertiary sediments from the northwest Atlantic. In Hollister, C. D., Ewing, J. I., et al., Init. Repts. DSDP, 11: Washington (U.S. Govt. Printing Office), 791-799.

Larson, V. F., Robson, V. B., and Foss, G. N., 1980. Deep ocean coring-recent operational experiences of the Deep Sea Drilling Project. 55th Ann. Fall Tech. Conf. and Exhibition, Soc. Pet. Eng. AIME, SPE 9409:1-9.

Markl, R. G., Bryan, G. M., and Ewing, J. I., 1970. Structure of the Blake-Bahama Outer Ridge. J. Geophys. Res., 75:4539-4555.

Moore, J. C., Watkins, J. S., and Shipboard Scientific Party, 1979. Middle America Trench. Geotimes, 24(2):20-22.

Paulus, F. J., 1972. Leg 11 measurements of physical properties in sediments of the western North Atlantic and their relationship to sediment consolidation. In Hollister, C. D., Ewing, J. I., et al., Init. Repts. DSDP, 11: Washington (U.S. Govt. Printing Office), 667-772.

Rice, D. D., and Claypool, G. E., 1981. Generation, accumulation, and resource potential of biogenic gas. Am. Assoc. Pet. Geol. Bull., 65:5-25.

Sayles, F. L., Manheim, F. T., and Waterman, L. S., 1972. Interstitial water studies on small core samples, Leg 11. In Hollister, C. D., Ewing, J. I., et al., Init. Repts. DSDP, 11: Washington (U.S. Govt. Printing Office), 997-1008.

Shipley, T. H., Houston, M. H., Buffler, R. T., Shaub, F. J., McMillan, K. J., Ladd, J. W., and Worzel, J. L., 1979. Seismic evidence for widespread possible gas hydrate horizons on continental slopes and rises. Am. Assoc. Pet. Geol. Bull., 63:2204-2213.

Stoll, R. D., Ewing, J., and Bryan, G. M., 1971. Anomalous wave velocities in sediments containing gas hydrates. J. Geophys. Res., 76: 2090-2094.

Tucholke, B. E., Bryan, G. M., and Ewing, J. I., 1977. Gas-hydrate horizons detected in seismic-profiler data from the western North Atlantic. Am. Assoc. Pet. Geol. Bull., 61:698-707.

von Huene, R., Aubouin, J., and Shipboard Scientific Party, 1980. Leg 67: the Deep Sea Drilling Project Mid-America Trench transect off Guatemala. Geol. Soc. Am. Bull., 91(pt. 1):421-432.

Whelan, J. K., and Sato, S., 1980. $C_{1}-C_{5}$ hydrocarbons from core gas pockets, Deep Sea Drilling Project Legs 56 and 57, Japan Trench transect. In Scientific Party, Init. Repts. DSDP, 56, 57, Pt. 2, Washington (U.S. Govt. Printing Office), 1335-1347.

Yefremova, A. G., and Zhizhchenko, B. P., 1974. Obnaruzheniye kristallgidradov gazov osadkakh sovremennykh akvatority. "Occurrence of crystal-hydrates of gases in the sediments of modern marine basins." Dokl. Akad. Nauk SSSR, 214:1179-1181 (in Russian); Dokl. Earth Sci. Sect., 214(1975):219-220 (in English).

Date of Initial Receipt: March 29, 1982 